\title{
FAZLî VE MANZUM KASÎDE-İ BÜRDE TERCÜMESİ
}

\begin{abstract}
Yunus KAPLAN*
$\ddot{O} z$

Çok zengin bir tercüme geleneğine sahip olan klasik Türk edebiyatında özellikle Arapça ve Farsça kaleme alınmış olan sayısız eserin yüzyıllar boyunca Türkçeye tercümesi yapılmıştır. Bu eserler içerisinde bazıları, sahip oldukları muhtevalarlyla mütercimlerin ilgisine daha fazla mazhar olmuş ve farkl mütercimler tarafindan defalarca Türkçeye tercüme edilmiştir. Bunlardan biri de Misırlı sûfì şair İmam Bûsîrî’nin on üçüncü yüzyllda Arapça tanzim ettiği ve temelini Hz. Peygamber'e duyulan derin muhabbetin teşkil ettiği Kasîde-i Bürde'dir. Edebiyatımızda Kemal Paşazâde, Leâlî, Ahmed-i Rıdvan, Şemseddin Sivâsî ve Nahîfi gibi onlarca şair tarafindan manzum tercümesi yapılan bu esere rağbet göstererek Türkçeye nazmen tercüme edenlerden biri de Paşa Sarayı Hocası santyla bilinen Fazlî'dir. Bu çalışmada önce Kasîde-i Bürde hakkında bilgi verilmiş, ardından özellikle emsali olan tercümelere nazaran daha edebî bir hüviyete sahip oluşuyla dikkatleri çeken Fazlî'nin bu kasideye yazdiğı 161 beyitten müteşekkil olan manzum tercümesinin şekil ve muhteva özellikleri üzerinde durulmuş ve tespit edilen beş nüshasından hareketle çeviri yazll metnine yer verilmiştir.
\end{abstract}

Anahtar Kelimeler: Bûsîrî, Kasîde-i Bürde, Fazlî, manzum tercüme.

\section{FAZLI AND HIS POETIC TRANSLATION OF QASIDAH AL- BURDAH}

\begin{abstract}
In classical Turkish literature, which has a very rich translation tradition, countless works written especially in Arabic and Persian have been translated into Turkish for centuries. Some of these works have attracted more attention of translators with their content and have been translated into Turkish many times by different translators. One of these is Qasidah Al-Burdah the Egyptian Sufi poet Imam Bûsîî arranged in Arabic in the thirteen century and was based on the deep love for Prophet. It is
\end{abstract}

\footnotetext{
* Doç. Dr., Osmaniye Korkut Ata Üniversitesi, Fen Edebiyat Fakültesi, Türk Dili ve Edebiyatı Bölümü, ORCID: 0000-0002-2421-253X

e-posta: yunuskaplan80@gmail.com
}

Geliş / Received: 28 Mayıs / May 2021

Kabul / Accepted: 6 Haziran / June 2021 
Kaside-i Bürde that is formed by the deep love felt for the Prophet. In our literature, one of those who translated this work into Turkish by showing the translation of poems by dozens of poets such as Kemal Pashazade, Leâlî, Ahmed-i Ridvan, Şemseddin Sivâsî and Nahîfî is Fazli, known as the Pasha Palace teacher. In this study, firstly, information about Kaside-i Bürde was given, then written text of the translation is included based on the five copies determined after focusing on the form and content features of the translation, which consists of 161 couplets written by Fazlî, who attracted attention with its more literary identity compared to the translations that are preceded.

Keywords: Bûsîrî, Qasidah Al-Burdah, Fazlî, poetic translation.

\section{Giriş}

Klasik Türk edebiyatı içinde teşekkül ettiği Osmanlı toplumunun sahip olduğu maddi ve manevi hemen hemen her unsuru merkezine alarak zenginleşmiş bir edebî gelenektir. Bu edebî gelenek içinde bu toplumun inanç temelini oluşturan İslamiyet'in ideal bir kul olmayı hedefleyen öğretileri, dünyevi ve uhrevi hayata müteallik hükümlerinin yanı sıra bu dinin tebliğcisi olan $\mathrm{Hz}$. Peygamber ve onun sahip olduğu özellikler her dönemde divan şairlerine ilham kaynağ 1 olmuştur. Hatta zamanla Hz. Peygamber'in nübüvveti, göstermiş olduğu mucizeleri, sahip olduğu fiziki ve ahlaki özellikleri ile Müslümanlara rehberlik eden örnek hayat tarzı gibi özelliklerini mihver edinen birçok edebî tür teşekkül etmiştir.

Bu meyanda siyer-i Nebî, mevlid, na't, bi'set-nâme, mu'cizâtü'nNebî, evsâfü'n-Nebî, gazavât-1 Nebî, vefatü'n-Nebî, hicret-nâme/hicretü'nNebî, esmâ-y1 Nebî, mi'râciyye/mi'râc-nâme, hilye, k1sas-1 enbiyâ, gazavât-1 Resûlullâh, kırk hadis, yüz hadis ve kısas-1 enbiya (Y1lmaz 2012: 145-312; Alıcı 2004: 129) gibi edebî türlerin teşkilinde divan şairlerinin Hz. Peygamber'e karşı hissettikleri derin muhabbetlerin tezahürleri önemli rol oynamıştır.

İster mürettep divanlarda veya mesnevilerde görülsünler ister küçük hacimli müstakil eserler şeklinde olsunlar tahmin edildiğinden daha bol ve zengin bir malzemeye sahip olan küçük veya büyük hacimli bu eserler, istisnasız Hz. Peygamber'e olduğu kadar çeşitli şekil ve türlerde asırlar boyunca başka biri için teşekkül etmemiştir (Çelebioğlu 1988: 357).

Hz. Peygamber'e olan muhabbetin bir tezahürü olarak divan şairleri tarafindan çokça rağbet gören eser türlerinden biri de kasîde-i bürdelerdir.

\section{Kasîde-i Bürde Hakkında}

Bir terim olarak kasîde-i bürde ifadesi, Arap kökenli iki şairin yazdığ 1 şiirler için kullanılagelmiştir.

Bunlardan ilki Ka‘b b. Züheyr'e (öl. 24/645) aittir. Câhiliye döneminin tanınmış Arap şairlerinden Züheyr b. Ebû Sülmâ ölmeden önce oğulları Kâ‘b ile Büceyr'e, gördüğü bir rüya üzerine gelmesinin yakın olduğunu anladığı Hz. Peygamber'e tabi olmalarını tavsiye eder. İki kardeş 
Medine'ye doğru yola çıkar. Kâ‘b, Medine yakınında kalır. Büceyr ise Medine'ye gider ve Resûl-i Ekrem ile görüşerek Müslüman olur. Bunu öğrenen Kâ‘b, kardeşini ve Resulullah'1 hicveden bir şiir nazmeder. Bunun üzerine Hz. Peygamber'in Kâ‘b'ın kanının helal olduğunu söylediği rivayet edilir. Büceyr kardeşine mektup göndererek bazı şairler hakkında ölüm kararı verildiğini, ancak Resûl-i Ekrem'in pişman olup huzura gelenleri affettiğini bildirir ve Hz. Peygamber'e gelip af dilemesini tavsiye eder. Medine'ye gidip sabah namazında Mescid-i Nebevî'ye giren Kâ‘b, Resulullah'ın huzuruna yüzü örtülü olarak çıkar ve kendisine Kâ‘b'ın tövbe edip İslam'1 kabul etmek amaciyla geldiğini, af talebinin kabul edilip edilmeyeceğini sorar. Resûl-i Ekrem talebinin kabul edileceğini belirtince yüzündeki örtüyü açar ve kendisinin Kâ‘b olduğunu söyler. Kâ‘b ünlü kasidesini bu sırada okumuş, kasideyi çok beğenen Hz. Peygamber de "Bürde" adı verilen hırkasını onun omuzlarına koymuş, bundan dolayı kasideye "Kasîdetü'l-bürde" veya başlangıç ifadesine göre "Bânet Sü'âd" adı verilmiştir (Demirayak 2001: 566-67).

Kasîde-i bürdelerden ikincisi ise Misırlı sûfî ve şair, Muhammed b. Saîd el-Bûsîrî’ye (öl. 696/1297?) aittir. Bûsîrî’nin Hz. Peygamber için yazdığı ve el-Kevâkibü'd-dürriye fì Medhi Hayri'l-Beriyye adını verdiği bu manzume, kafiye (revî) harfi mîm olduğu için el-Kasîdetü'l-Mîmiyye, şairin tutulduğu hastalıktan kurtulmasına vesile olduğu için de Kasîdetü'l-Bürde diye meşhur olmuştur. Ancak Kâ‘b b. Züheyr'in kasidesi de aynı adla anıldığından karışıklığa meydan vermemek için Bûsîrîninki daha çok Osmanlı kültür muhitinde Kasîdetü'l-Bür'e şeklinde anılmışsa da literatürde Kasîdetü'l-Bürde diye tanınmaktadır (Kaya 2001: 568).

Bu kaside, şöhretini taşıdığı sanat değerinden ziyade şairin hayatının bir döneminde geçirdiği felçten kurtulmasına vesile olduğuna dair rivayete borçludur. Söz konusu rivayete göre felç geçirdiğinde bir akşam kendisine şifa vermesi için Allah'a dua eden şair, rüyasında Hz. Peygamber'i görür. Resûl-i Ekrem ondan kendisi için yazdığı kasideyi okumasını ister. Bûsîrî, "Yâ Resûlallah! Ben senin için birçok kaside yazdım, hangisini istersin?" deyince Hz. Peygamber kasidenin ilk beytini söyler. Bunun üzerine şair kasidesini okumaya başlar, Hz. Peygamber de onu sonuna kadar dinler. Bitince de hırkasını (bürde) çıkarıp şairin üstüne örter ve eliyle vücudunun felçli kısmını sıvazlar. Bûsîrî, uykudan uyanınca vücudunda felçten eser kalmadığını fark eder. Bu rüya hadisesinin halk arasında yayılmasından sonra kaside, Kasîdetü'l-Bürde olarak üne kavuşmuştur (Kaya 2001: 568).

Aruzun "müstef'ilün fâ 'ilün müstef'ilün fe 'ilün" kalıbıyla yazılan bu kaside, en eski nüshalarında 160 beyit iken daha sonraki nüshalarda 165 beyte kadar çıkmaktadır. Klasik Arap kaside tarzında olduğu gibi şiir, sevgiliye özlem temasının işlendiği nesib bölümüyle başlar. Daha sonra nefisten şikâyet, Hz. Peygamber'e övgü, onun doğumu, mucizeleri, Kur'ân'ın fazileti, mi'rac mucizesi, cihadın önemi, nedamet ve ümit, dua ve niyaz bölümüyle sona erer. Yapı ve üslup bakımından son derece sağlam ve lirik olan kaside, bu sebeple asırlardır İslam coğrafyasının her bölgesinde büyük bir ilgi görmüş, dinî toplantılarda, mübarek gün ve gecelerde, sünnet, dügün, bayram ve cenaze merasimlerinde okuna gelmiştir. Haftalık evrad olarak da okunan kaside, 140. beytinden itibaren felçlilere şifa maksadıyla yedi gün süreyle okunmaktadır (Kaya 2001: 568-69). 
Farsça, Malayca, Peştuca, Pencapça ve Urduca gibi doğu lisanları yanında Almanca, Fransızca, Grekçe, İngilizce, İspanyolca, İtalyanca, Latince gibi dillere de aktarılan (Kaya 2001: 569) Kasîdetü'l-Bürde; birçok Müslüman milletlerde olduğu gibi Türk şair ve nasirleri tarafından da çok büyük bir rağbet görmüştür. Eserin manzum ve mensur olmak üzere yirmi civarında Türkçe şerhi ve otuz civarında Türkçe tercümesi bulunmaktadır (Şahin 1997; Yazar 2011). Bu manzume üzerine ayrıca çok sayıda hâşiye, tahmîs, tesdîs, tesbî̀ ve taştîr de kaleme alınmıştır (Yazar 2011: 587). ${ }^{1}$

$\mathrm{Bu}$ çalışmanın mihverini de onlarca şair tarafından tercüme, şerh, tahmîs veya tazmini yapılan İmam Bûsîrî'nin kasidesine Paşa Sarayı Hocası Fazlî’nin Türkçeye manzum tercümesi teşkil etmektedir.

\section{Fazlî ve Manzum Kasîde-i Bürde Tercümesi}

Fazlî’nin Kasîde-i Bürde Tercümesi’nin dördü Millî Kütüphane (06 Mil Yz A 149, 06 Mil Yz A 4639/1, 06 Mil Yz A 3963/2, 60 Zile 444/1), ikisi Süleymaniye Kütüphanesi (Reşid Efendi 826, İbrahim Efendi 878) ve biri de Ankara Üniversitesi İlahiyat Fakültesi Kütüphanesinde (EY 0747) olmak üzere şimdilik tespit edilen yedi nüshası bulunmaktadır.

\subsection{Eserin Mütercimi ve Tercüme Tarihi}

Üzerinde çalıştığımız manzum Kasîde-i Bürde Tercümesi'nin mütercimi olan Fazlî hakkında eldeki bilgiler yok denecek kadar azdır. Mütercimin ismi veya mahlası olan Fazlî ve Paşa Sarayı hocası olduğu dışında elde herhangi bir bilgi bulunmamaktadır. Ancak eserin Millî Kütüphanede "06 Mil Yz A 3963/2" arşiv numaralı nüshasının başında müstensih, Kasîde-i Bürde'nin faziletlerinden bahsettikten sonra bu eserin Paşa Sarayı Hocası Fazlî Efendi tarafından 1036/1626-27 tarihinde nazmen tercüme edildiği bilgisini vermiş ve kendisinin de asıl nüshadan istinsahta bulunduğunu ifade etmiştir. Bu ifade, Fazlî’nin bu eserini hem 1036/1626-27 yılında kaleme aldığını hem de bu tarihte hayatta olduğunu göstermektedir.

Biyografik kaynaklarda mezkûr tarihte hayatta olduğu bildirilen Fazlî mahlaslı herhangi bir şaire rastlanmamaktadır. Fakat hayatı hakkında tezkirelerde ve biyografik kaynaklarda bir bilgi bulunmasa da 1040/1636-37 yılında kaleme almış olduğu Mahzenü'l-Esrâr adındaki eseri vesilesiyle haberdar olunan Vardarlı Fazlî’nin varlığ bilinmektedir (Aksoyak 2013). Ne var ki Vardarlı Fazlî'nin Kasîde-i Bürde'yi nazmen tercüme ettiğine dair herhangi bir kayda rastlanmaması, üzerinde çalıştığımız eserin müterciminin kim olduğuna dair soruları da cevapsız bırakmaktadır.

\section{2. Şekil ve Muhteva Özellikleri}

Bazı Kasîde-i Bürde tercümelerinde karşımıza çıkan ve mütercimlerin eserlerini kaleme alma sebeplerini bir vesileyle dile getirdikleri hamdele-salvele, tevhit, na't veya sebeb-i telif gibi mukaddime

\footnotetext{
${ }^{1}$ Türk edebiyatında oldukça fazla rağbet gören İmam Bûsîrî ve Kasîde-i Bürde'sine yazılan şerh, tercüme ve diğer eserler hakkında şimdiye kadar birçok çalışma yapılmıştır. Yapılan bu çalışmalarla ilgili daha ayrıntılı ve derli toplu bilgi için bak. (Sezer 1985), (Şahin 1997), (Kaya 2001), (Yazar 2011), (Yücel 2016).
} 
kabilinden bölümler²; Fazlî’nin Kasîde-i Bürde Tercümesi'nin şimdilik tespit edilebilen nüshalarında bulunmamaktadır.

Fazlî, Arapça 161 beyit olan kaynak metnin doğrudan tercümesine geçmiş ve eseri, yine 161 beyit hâlinde Türkçeye tercüme etmiştir. Şair, aruzun "müstef'ilün fấilün müstef'ilün fe 'ilün" veznine sahip olan kaynak metinden farklı olarak "mefâ îlün mefâ î̀lün mefâ îlün mefầîlün" kalıbını tercih etmiş ${ }^{3}$ ve metnin tanziminde aruzu başarıyla tatbik etmesini bilmiştir. Bunu yaparken birçok şair gibi zaman zaman çeşitli aruz tasarruflarına başvurmak zorunda kalsa da bu tasarruflar metnin ahengine halel getirecek mahiyette değildir.

Kasîde-i Bürde'nin bilinen manzum tercümelerinin çoğunda şairler, kafiye olarak kaynak metinle aynı kafiyeyi tercih etmişlerdir. ${ }^{4}$ Fazlî'nin tercümesi vezin hususunda olduğu gibi kafiye bakımından da kaynak eserden farkl1lik arz etmektedir. Kaynak metin sadece revi harfinden ( $)$ ) oluşan mücerred kafiyeye sahip iken; Fazlî̀nin tercümesi revi ve ridf harflerinden $(1+\dot{\text { }})$ oluşan mürdef kafiyeye sahiptir. Eser, bu hâliyle kafiye bakımından Zâtî ve Şemseddin Sivâsî'nin manzum tercümesiyle aynı özelliğe sahiptir.

Her ne kadar İmam Bûsîrî, kasidesini tanzim ederken belirli bölümlere ayırmamış olsa da şarihler ve mütercimler beyitlerde dile getirilenlerden hareketle bu kasideyi on bölüm hâlinde ele almışlardır. Bûsîrî'nin kasidesinde olduğu gibi Fazlî'nin manzum tercümesi de beyitlerde işlenen konular göz önünde bulundurulduğunda 10 bölümden meydana gelmektedir. Muhteva bakımından bu bölümlerde işlenen konular şunlardır:

1. Hz. Peygamber'e olan hasret ve ona duyulan sevgi (1-12. beyitler)

2. Nefsin tuzakları ve nefisten şikâyet (13-28. beyitler) beyitler)

3. Hz. Peygamber'in medhi ve sahip olduğu güzel vasıflar (29-58.

4. Hz. Peygamber'in doğumu ve bu esnada gerçekleşen olağanüstü hadiseler (59-71. beyitler)

5. Hz. Peygamber'in göstermiş olduğu mucizeler (72-87. beyitler)

6. Kur'ân-1 Kerîm'in sahip olduğu özellikler (88-106. beyitler)

7. Mi'rac mucizesi ve bu esnada yaşanan bazı hadiseler (107-117. beyitler)

8. Hz. Peygamber'in cihadı, şecaati ve sahabenin göstermiş olduğu kahramanlıklar (118-139. beyitler)

\footnotetext{
${ }^{2}$ Örneğin Amasyalı Seyyid Hüseyin Efendi ve Diyarbakırlı Mehmed Said Paşa'nın Kasîde-i Bürde tercümeleri, bu tarz bölümlere sahiptir.

${ }^{3}$ Eser, yazılmış olduğu vezin itibarıyla bu türdeki Zâtî ve Kemâlâtî Mehmed'in manzum tercümeleriyle ortak özelliğe sahiptir.

4 Ahmed-i Ridvân, Sayrafî, Diyarbakırlı Mehmed Said Paşa, Esâsî, Kemalpaşazâde, Nahîfî, Hulvî ve Selahaddin Uşşâkî’nin manzum tercümeleri Bûsîrî’nin kasidesiyle aynı kafiyeye sahiptir.
} 

beyitler)

9. İşlenen günahlardan nedamet ve bunların af talebi (140-151.

10. Allah'a münacat (152-161. beyitler).

Fazlî’nin manzum tercümesi, bu bölümlerde zikredilen muhteva itibarıyla her ne kadar kaynak metnin muhtevasıyla mütenasip olsa da birebir tercüme değildir. Şair, kaynak metnin beyitlerinde serdedilen manayı zihninde meczetmiş, bir şair olarak bunları gönlündeki ve ruhundaki coşkunlukla birleştirerek tekrar nazım kalıbında şekillendirmede oldukça başarılı olmuştur.

Klasik Türk edebiyatında kaynak metinlerdeki özel isimler, kültürel özellikleri bulunan kelimeler, deyimsel ifadeler, dilde sapmalar, belagat özellikleri yanında; nazım biçimi, vezin ve kafiye gibi biçimsel özellikler gibi birçok zorluğu bünyesinde barındırmış olmasına rağmen özellikle Arapça veya Farsça manzum metinler yine manzum olarak Türkçeye tercüme edilmiştir (Yazar 2018: 155). Hâl böyle olunca yapılan bu tercümelerde gerek ifade gerekse de bazı kelime ve ibarelere Türkçe karşılık bulmada mütercimler zaman zaman çeşitli müşküllerle karşılaşmışlardır. Bu müşküller, kaynak eserdeki kelimelerin karşılığ 1 verilmeden aynen tekrar edilerek veya bu kelimelere karşılık Arapça veya Farsça kökenli kelimeler kullanılarak aşılmaya çalışılmıştır.

$\mathrm{Bu}$ şekilde kaynak eserde kullanılan kelimelerden bir kısmının karşı1lı̆ı̆nın verilmeden aynen tekrar edilmesi, birçok tercüme eserde olduğu gibi Kasîde-i Bürde tercümelerinde görülen yaygın olan ortak özelliklerden biridir. Fazlî de tercümesinde "muhârim, garf, "izam, hereb, hasyâ, ebtâl, mültakim, lems, eşheb, tetâvul, muhdes, sekam, nebt, karm" gibi İmam Bûsîrî'nin kasidesinde kullandığı bazı kelimeleri Türkçeye tercüme etmeden aynen kullanmıştır. Şairin böyle bir tercihte bulunmasını, lafızdan ziyade anlamı çevirmeye çalışması ve aslına uygun bir tercüme yapma gayretiyle bu kelime ve kavramlara Türkçe karşılık bulmada zorlanmış olmasıyla da açıklamak mümkündür.

Yukarıda da zikredildiği üzere Kasîde-i Bürde tercümelerinde şairler, kaynak dil olan Arapçadan hedef dil olan Türkçeye tercüme yaparken Arapça kelimelere Türkçe karşılık bulmada karşılaştıkları zorlukları aşmak ve mevzun-mukaffa edebî hüviyeti haiz bir metin tanzim etmek için genellikle Arapça ve Farsça kelimeler kullanma yoluna gitmişlerdir. Mütercimlerin yerine göre mecbur kaldıkları bu duruma Fazlî'nin tercümesinde de şahit olunmaktadır. Aşağıdaki beyit, özellikle ihtiva ettiği Arapça kelimeler bakımından bu duruma güzel bir örnek teşkil etmektedir:

\section{Nevāfilden ne i`dād eyledüm ben mevtden evvel}

Ferā '̇żden șalāt u șavma hașr idüp dil ü cānı $\quad$ b. 28

Ebubekir S1ddık Şahin, Kasîde-i Bürde'ye yazılan 23 manzum tercümenin şekil ve muhteva özelliklerinden hareketle bu tarzda tanzim edilen tercümeleri "asıl metne harfiyen bağlı kalanlar" ve "çeşitli yönlerden asıl metinden ayrılanlar" olmak üzere iki gruba ayırmıştır. Birinci gruptaki tercümelerin şairlik kudreti zayıf kişiler veya metni harfiyen tercüme etmeyi taassup derecesinde benimseyenlerce yazıldığını söyleyerek Kemalpaşazâde, Ahmed Rıdvan, Abdulhay Efendi, Nahîfî ile Salâhi Uşşâkî'yi bu gruba; 
Kemâlâtî Mehmed, Fazlî, Kudsîzâde Kadrî ve Abdulhalim Kenan'1 ise metne bağlılıktan çok şîve-i şi'riyyenin ön planda tutulduğu ikinci gruba dâhil etmiştir (1997: 131-32).

Şahin'in de belirttiği gibi Fazlî, tercümesinde anlam itibarıla kaynak metne sadık kalmaktan ziyade; şairlik kudretinin verdiği ilham ve sahip olduğu istidatla birlikte zihninde oluşan anlam katmanlarını vezin, kafiye ve kaside nazım şeklinin kalıplarına başarılı bir şekilde uydurarak edebî değeri haiz yeni ve özgün bir metin ortaya koymasını bilmiştir.

Klasik Türk edebiyatında bir eserin çokça istinsah edilmiş olması, bu eserin çok beğenilip okunduğunu gösteren önemli kıstaslardan biridir. Kasîde-i Bürde üzerine tanzim edilen manzum tercümelerin de hem sayıca fazla oluşu hem de bunlar içinde bazılarının bolca istinsah edilmiş olması bu türün okur kitlesi nezdinde mazhar olduğu ilgiyi göstermektedir. Bu meyanda manzum tercüme kaleme alan otuz civarındaki şair içinden sırasıyla Hulvî, Leâlî, Şemseddin Sivâsî ve KemalPaşazâde'nin eserleri en fazla istinsah edilen eserlerdir. Fazlî'nin Kasîde-i Bürde Tercümesi’nin de şimdilik tespit edilebilen yedi adet nüshasının bulunması, eserin bu tür içinde belli bir şöhreti yakaladığını göstermesi bakımından önemlidir. Daha ayrıntılı araştırma, inceleme ve taramalar neticesinde bu sayının daha da artabileceğini de göz ardı etmemek gerekir.

\title{
3. Çeviri Yazılı Metin
}

\section{Fażìletli Paşa Serāy Hुāàce[si] Olan Fażlī Efendinüñ Terceme İtdügi Kașidenüñ Vezni Baḥr-1 Basị̄ Maḩbūndur Tercemesinüñ Hezec-i Sālimdür ${ }^{5}$}

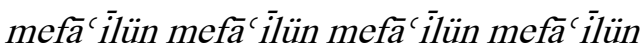

1. Dilā añduñ mı ol āhū baḳışlu yār-i Ken`ānı

Ki halṭ itdüñ dem-i ' unnābuña eşk-i firāvānı

2. Yahod bād-1 șabā mı esdi iḳlīm-i dil-ārādan

Ya ol zülf-i siyehden şu' leler mi urdı rahşāni $\bar{i}$

3. Ne geldi ' aynuña nuṣhum olur țugyaānına bā' is

Ne oldı ${ }^{6}$ ḳalbüñe kim yine efzūn itdi heymānı

4. 'Aceb derd-i derūnın münketim mi z̧ann ider 'āşık

\footnotetext{
${ }^{5}$ Başlık: -M2, M3, S1, S2, İ.

Metinde nüsha farkları gösterilirken Milli Kütüphane Yazmalar Koleksiyonu, "06 Mil Yz FB 149” için M1, “06 Mil Yz A 4639/1" için M2, “06 Mil Yz A 3963/2” için M3; Süleymaniye Kütüphanesi “İbrahim Efendi 878/3" için S1, "Reşid Efendi 826” için S2, Ankara Üniversitesi İlahiyat Fakültesi "EY 0747” için ise İ kısaltmaları kullanılmıştır. Milli Kütüphane Yazmalar Koleksiyonu "60 Zile 444/1" numaralı nüsha ise hem baştan eksik oluşu hem de rutubetten dolayı mürekkep dağılmalarının bazı yerlerde metnin okunmasına imkân tanımadığı için karşılaştırmalı metne dâhil edilmemiştir.

${ }^{6}$ Ne old1: Ya n'old1 M1; Ne geldi M2.
} 
Nümāyān eylemişken çeşm-i terle ḳalb-i sūzānı

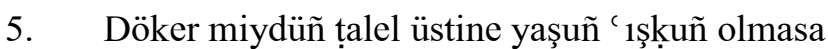

Uyanıḳ mı ḳalurduñ yād idüp ol ḳāmet-i bānı

6. Pes ey ' āşık niçe inkār idersin ḥālet-i ' $1 s ̧ k ̣ 1$

'Adūl-i dem' ü saḳmuñ eyledükden șoñra i' lānı

7. Ya issbāt eylemişken ruhlaruñ iki gül-i aṣfer

Yahod eşk-i revānuñ iki ḩațț-1 ạ̣mer-i ḳanı

8. Beli geldi hayāli dīde-i cāna veli ḳ̂ldı

Benüm bu cism-i zārum maẓhar-1 ālām u aḥzānı

9. Melāmet itme ey lā 'im beni sevdā-y1 ‘ özrīide

Eger inșāf ideydüñ ‘āşıḳa eyler m’idüñ anı

10. Şu derd-i bi $\bar{i}$-devāya ${ }^{7}$ ben ki düşsüm sen de meftūn ol

'Adūdan șaḳlamaḳdan ḳaldum ol ḥāl-i perişsānı

11. Baña luțf u keremler eyleyüp bir nuṣh-1 șāf itdüñ

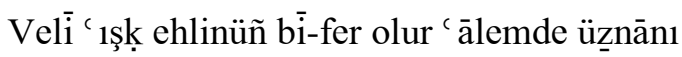

12. Melāmet eyledükçe töhmet itdüm nāșiḥ-i şeybe

Cihānda yog iken anuñ gibi bir nāṣiḥ-i sāni

13. Ṣabāvetler idüp emmāre nefsüm țutmadı nuṣhı̣ın

Aña pend ü nașihhatler iderken şeyb-i nūrānī

14. Ne i` dād eyledi ' ālemde bir kār-1 pesendīde

Ne iț ām eyledi başındaki ol żayf-1 Yezdāni

15. Eger bilseydüm ol şeybe kemāl-i nefy-i ikrāmum

Ketemle ketm iderdüm şöyle bādi ḳormıdum anı

16. 'Aceb kim redd ider emmāre nefsüñ farț-1 țuggyānın

Licām ile şu ${ }^{8}$ esb-āsā kim olur șāḥib-i șānī

${ }^{7}$ bì-devāya: bī-devā kim M2; İ. 
17. Șafā-yı ma' șiyetle umma kesr-i şehvet-i nefsi

Kim iṭ ām eyledükçe țurmaz artar hırș-1 hayvānī

18. Şu țffla beñzer ol kim ger ḳonulsa terk-i şìi itmez

Konulmasa eger ol aȟ ider emr-i nigehbānı

19. Pes anı żabṭ idüp kendüñe vāli eyleme yohssa

Helāk ider ${ }^{9}$ yahod îrās ider bir vaṣma-i cānı

20. Șalāḥ içinde olduḳça mürā' àt eyle aḥvālin

Koyıvirme eger mer āsına eylerse cevlān $1^{10}$

21. Niçe lezzzetleri tezyīn idüp min-hayșü lā-yedrī ${ }^{11}$

Helāk itdi niçe merdāne-i şāh-1 cihānbānı

22. Fesād u fitne-i cū' u şeb ${ }^{c}$ adan ictināb it kim

Niçe cū' uñ şiba' dan artuḳ olur rūy-1 hüsrānı

23. Aḳıt yaşuñ şu gözden kim pür olmışdur mahārimle

Gerekse kendüñe mu tād idin hūỳ-1 peşīmānı

24. Hulāf-1 ma' șiyet eyle hevā-yı nefs ü şeyțāna

Eger bir nuṣh-1 șāf eylerse göster farṭ-1 țugyānı

25. İtầ at eyleme a dā-yı dīne her ne olursa

Ki saña bunlaruñ mahfīi degüldür hạāet ü şānı

26. Şu ḳavl-i bì-` amel kim itdüm aña tevbeler olsun

Ki nisbet eyledüm ben bir ` akỉme nesl-i sulțānı

27. Saña ḩayr ile emr itdüm veli ben țutmadum emri

Pes ol ḳavlüñ nedür ma' nisisi göster rūy-1 tibyānı

28. Nevāfilden ne i` dād eyledüm ben mevtden evvel

\footnotetext{
${ }^{8}$ şu: çü M1.

${ }^{9}$ ider: eyler M2, İ.

${ }^{10} \mathrm{Bu}$ beyit, S2'de yok.

${ }^{11}$ lā-yedrí: lā-tedrì M2, İ.
} 
Ferā 'iżden șalāt u șavma hașr idüp dil ü cānı

29. 'Aceb zulm eyledüm rāhına ol şāhuñ kim ihyāda

Teverrümler iderdi țurmadan ol pāy-1 rahşsānı ${ }^{12}$

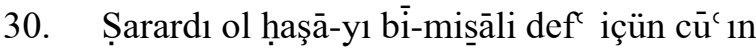

Ṭutardı bir iki seng ile cāy-1 pāre-i nānı

31. Cibāl-i Şüm aña altun olup ' arż-1 cemāl itdi

Veli meyl itmeyüp gösterdi bir enf-i Süleymānı

32. O faḳr ile bu istiğnāsı te 'kìd eyledi zühdin

Żarūret niçe ỉrās eyleye ma' șūma noḳșānı

33. Yahod dünyāya anı niçe da' vet eyleye ol kim

Dilenmezdi eger ol olmasa bu kān-1 imkānı ${ }^{13}$

34. Muhammed muḳtedā-y1 'ālem-i dünyā vü 'uḳbādur

Kim oldur mübtedā-yı cümle-i efrād-ı insānı

35. Bize şol āmir ü nāhìiür ol kim ḳavl-i pākinde

Kemāl-i ṣıdḳ u birrinde bulunmaz anuñ aḳrānı

36. Şu maḥbūb-1 Hudādur ol kim ehvāl-i ḳıāmetde

Günehkār-1 cihān andan umarlar derde dermānı

37. Cenāb-1 Ḥażret-i Bārīye hualḳı eyledi da' vet

Ṭutan anı țutar bir ' urve-i vüșḳā-yı Rahmānı

38. Nebiyyine tefavvuk eyledi halk ile hulḳında

Müdāni olmadı ‘ ilm ü keremde aña bir dāni

39. Şifā-yı șadr içün bunlar o şehden iltimās eyler

Ya bir garf-1 yem-i bì-ḥadd ü ya bir reşf-i bārānı

40. Cemī` enbiyānuñ müntehā-yı hikmet ü 'ilmi

\footnotetext{
12 rahşāñ: dırahşānı İ.

${ }^{13}$ İ. Nüshasında müstensih, 33 ile 60. beyitler arasını Fazlî'nin yerine Şemseddin Sivâsî'nin manzum tercümesindeki beyitleri kaydetmiştir.
} 
O şāh-1 ser-firāzuñ mübtedā-yı ‘ ilm ü ‘irfānı

41. Pes anuñ șūret ü ma`nīsi bunlardan etem oldı Anuñçün Hुālıḳı kendüye maḥbūb eyledi anı

42. Mehāsinde o şāh-1 bī-naziire bir şerik olmaz Bulunmaz cevher-i pākīze-i hüün-i dırahşānı

43. Nașārānuñ o ḳavl-i bāṭlından ictināb eyle Veli andan öte her neyse olsun ol nümāyānı

44. Şerefden zāâtına her ne dilerseñ eyle nisbetler 'İzạamdan ḳadrine her ne dilerseñ ol sühandānı

45. Kim anuñ fażlına ḥadd ü nihāyet yoḳ ki bir nāṭ̣̂ Zebān ile nümāyān eyleye ol hạadd ü pāyānı

46. Eger āyātı kadrince olaydı ruḳbe-i ismi Ṭı $1 \bar{a}^{\complement}-1$ rimmiye işrāb ideydi āb-1 ḥayvānı

47. Bize şol imtihān̄ı itmedi kim ḩadş ider 'aḳlı Anuñçün çekmedük biz de belā-yı rūy-1 heymānı

48. Verāyı eyledi ic yā o şāhuñ fehm-i ma' nāsı Beyānı nice i’ cāz itmesün Ḥassān u Sehbānı

49. Şu şemse beñzer ol kim bu' $d_{1}$ ile gösterür küçük Velī ḳurbı ile ${ }^{14}$ ic $^{\text {c }}$ à ider erbāb-1 imª̄nı

50. Niçe idrāk ider dünyāda künh-i zāâtını anuñ Şu nā 'im kim tesellīler bulur rü 'yā ile cānı

51. O şehde meblag -1 ' ilmi budur kim bir beşerdür ol Kim anı hayr-1 ḩalḳ eylemişdür luṭ̂-ı Yezdāni

52. Her āyet kim getürdi ḳavmine Rüsl-i kirām-1 Hak Anuñ nūrından aldı bunlar ol şem '-i firūzānı

\footnotetext{
${ }^{14}$ kurb1 ile: kurb eylese S2.
} 
53. O bir şems-i fażìletdür ki bunlar encüm-āsādur Yaḳarlar halk içün zulmetde bir şemc -i şebistāni

54. Nedür ol halḳ-1 zỉbā kim müzeyyen eyleyüp hulḳ1 İhāṭa eylemiş gülzār-1 hüüsni verd-i ḩandānı

55. Terefde bir gül-āsādur şerefde ' ayn-1 bedr olmış Himemde pest ider dehri keremde keff-i ' ummānı

56. Mülāḳāt eyledükde ferd iken farț-1 celāletden Şu leşkerde șanurduñ kim bulunmaz ḥadd ü pāyānı

57. Ṣadef gibi dehān-ı pākini açsaydı ețrāfa Le'āli neşr iderdi ma' den-i nuṭ̣̂ı vü dendānı

58. Bu dehrüñ țybı olmaz ṭ̂yb-1 hāk-i ḳabrinüñ ' adli Sa`ādet aña kim ḳoḳdı o hāk-i ‘ anber-efşānı

59. İbāne eyledi cāy-1 vilādı ṭıb-1 aṣlından Gel ey ṭıyb-1 murād cān-1 pāk-i evvel ü s̄āni

60. O bir gündür ki ol günde tefattun eyleyüp Fāris Yine ug̉radığını bildiler erbāb-1 țug̉yānı

61. Tekessür eyleyüp Kisrānuñ eyvānı o sā' atde O huavf ile tefarruḳ eyledi enșār u a' vānı

62. Söyindi āteş-i Kisrā bu hāle farṭ-1 hüzninden Yañıldı yolını nehri bu kāruñ oldı hayrānı

63. Yem-i Sāve zemine geçdi ehli gamlara batdı Girüye döndiler gayẓ u gażabla cümle 'ațşānı

64. Bükālar eyledi gūyā bu kāra āteş-i Kisrā Harāretler tutup ol mā'-i sermā oldı sūzānı

65. Taharrük eyleyüp envārı cinnīler nidā itdi O gice lafẓ u ma` níden nümāyān oldı bürhānı 
66. Bu ḳavme kūr u kerlikden ne mesmūc oldı tebşīi Ve ne manzūurr ${ }^{15}$ oldı tìg-i inzār-1 kemākānı

67. Dimişken bunlara kāhinleri şimdengirü țurmaz

Y1ḳ1ldı millet-i ‘ avcāñizüñ ețrāf u erkānı

68. Yahod ufk-1 semāda görmiş iken remye-i şühbi Ya aḳtārr-1 zemīne sıḳtạ-i aṣnām u evșānı

69. Şu deñlü oldı kim țarf-1 semāda farț-1 zahmmından Biribirinüñ ardınca ḳaçurdı cümle şeyțānı

70. Herebde ${ }^{16}$ döndiler ${ }^{17}$ bunlar ya ebțāl-i Necāşīye Yahod şol cem`a kim hașbā ile remy eyledi anı

71. Atıldı zikr idüp keff-i şerifinden şunuñ gibi Kim eylerdi haşā-yı mültaḳimde żikr-i Raḥmānı

72. $\mathrm{Du}^{\mathrm{c}}$ āsına icābet eyledi eşcār secdeyle Çıḳup bir sāḳ-ı bì-pā ile țutdı emr ü fermānı

73. O sāk ile yine yirine ' avd ${ }^{18}$ itdi o sā' atde $^{19}$ Fürūc ile kitābet eyleyüp bir hatṭ-1 reyḥāni

74. Şunuñ gibi ki her ḳanda giderse tāb-1 mihrinden Sehāāb ile viḳāyetler iderdi luṭf-1 Yezdānī

75. Yemīn itdüm meh-i münşakḳa kim bir intisāb itdi O ḳalb-i șāfa kim şaḳk itdi anı dest-i ${ }^{20}$ Raḥmāni

76. Ya şol hayr u kerem gibi kim ol mạ̣viyy-i gāàr oldı Velī ehl-i żalāluñ gāa döndi gitdi ‘ aynānı

\footnotetext{
${ }^{15}$ manzūur: manzūūr S2.

${ }^{16}$ Herebde: ' Arabda M1.

${ }^{17}$ döndiler: țutd1lar İ.

18 'avd: ' avdet M1, İ.

${ }^{19}$ o sā' atde: ol demde İ.

${ }^{20}$ dest-i: yed-i M2.
} 
77. Pes ol gāaruñ içindeydi Hudānuñ ṣıdk u Ṣıddīḳi

Velï dirlerdi kim yoḳdur burada ferd-i insānı

78. Ḥamām u ' ankebūtuñ nesc ü devri șābit olmış iken Yine bunlar șanurlardı ki yoḳdur nesc ü devrānı ${ }^{21}$

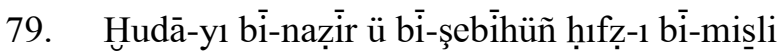
Ḥ̂fāẓ-1 ḳal' a vü cevşenden itdi bunları gānīi ${ }^{22}$

80. Bu dehr-i bì-vefā cevr ü cefã itdükçe ben aña Ṣıg̀ınmag ile buldum dürlü dürlü luṭf u iḥsānı

81. Baña her ne murād itdümse virdi keff-i cūdından O şeh göstermedi mir 'àt-i dilde rūy-1 ḥırmānı ${ }^{23}$

82. Ṣaḳın rü 'yādaki vahyinini inkār eyleme anuñ Ki ḳalb-i șāfı uymazdı eger uysaydı ` aynānı

83. Bu i lāmı nübüvvetde bülūg̀̀ 1 demlerindeydi O demlerdeyse nefy olmaz Nebinüñ rü 'yet-i cānı

84. Te âlā eyledi Allāh degüldür mükteseb vahyi Getürmez töhmeti gayba nebiyy-i șāhịib-i izzānı

85. Şifã virdi niçe ehl-i belāya luṭf-1 lemsinden Halāṣ itdi cünūnından niçe bì- aḳl u ižc ānı

86. Dirildi sāl-i eşhebler du' à-yı müstecāb ile Şu gurre gibi oldı kim ihạạta itdi sūdānı

87. Şu 'ārıżla ki cūd itdi bițāha țoldı șanınca ${ }^{24}$ Ya bir seyl-i ‘ Arim yahod bir āb-1 seyb-i ' ummāni

88. Koñuz vaṣf ideyin şol āyetin kim zāhir olmışdur O şol nār-1 ḳırā gibi ki șalmış nūr-1 a lānı

\footnotetext{
${ }^{21} 78$ ile 92 . beyitler aras1 M2'de eksiktir.

${ }^{22}$ itdi bunları gaānì: a' lā ṣaḳladı anı İ.

${ }^{23}$ ḥırmānı: rahş̧ānı M1 .

${ }^{24}$ șanınca: z̧ann ile İ.
} 
89. Ki lü 'lü ' hüsnini efzūn ider ger muntaẓam olsa Eger olmasa virmez ${ }^{25}$ meblag̀-1 hüsnine nokșānı

90. Tețāvul eylemez āmāl-i vașșāfi şu ahlāḳa Kim anı aña iḥsān eylemişdür luṭf-1 Rabbānīi ${ }^{26}$

91. Şol āyāt-1 Hudādur ol kim anuñ lafẓı muhdeșdür Velì ma' nìsi ber-vașf-1 ḳadīm-i zaāt-1 Raḥmāni

92. Zamāna muḳterin olmaz velī hạali budur țurmaz Bize ihbbār ider ' Ād u İremle ḥaşr-i cismānīi ${ }^{27}$

93. Tefavvuk eyledi i` cāzı i` cāz-1 Nebiyyīne Bu geldükde te atțul itdüg'içün hüükm-i burhānı

94. $\mathrm{Ne}^{28}$ muhkemdür o kim ehl-i şiḳāḳa şübheler ḳor $\mathrm{mi}^{29}$ Yahod naṣb-1 hakem mi ister anuñ rıf $f^{\complement}$ at-1 şānı

95. 'Adūl itdi harabdan her kim anuñla cidāl itdi Maḳarr oldı kemāl-i kuvvet-i bāzū-yı Ḳur 'ānı ${ }^{30}$

96. Çıḳardı hașmını żarb ile meydān-ı belāgagatdan Haremlerden sürüldi gūyiyā dest-i çep-i cānı

97. $\mathrm{Me}^{\mathrm{c}}$ ānisi mededde aşag̉ı ḳor mevc-i deryāyı Le'ālisi ḳıemde hatṭ ider lü 'lü'-i 'ummānı

98. Mecāl olmaz anuñ ḥāl-i ' acībin ' add u ihṣāya Se 'āmet virmez erbāb-1 dile ikṣār-1 Kur ’ān $1^{31}$

99. Münevver oldug' 'içün ḳāri 'innüñ gözleri didüm İrişdük habl-i Bāriye ḳoyıvirme șaḳın anı

\footnotetext{
${ }^{25}$ virmez: virimez M1.

${ }^{26} 90$ ile 99 . beyitler aras1 M1'de eksiktir.

${ }^{27}$ cismānī: mīzānı İ.

${ }^{28} \mathrm{Ne}$ : Şu M3, S2.

${ }^{29}$ kor m1: mi kor M2; komaz İ.

${ }^{30}$ Kur ānı: burhānı S2.

${ }^{31}$ Kur ānı: güftārı S2 .
} 
100. Tilāvet eyledüñse hyavf-i nīrān-1 cehennemden $O$ vird-i pür-şebemle ${ }^{32}$ eyledüñ ițâa o nīrānı

101. Şu ḥavża beñzer ol kim anuñ ile nūrlar bağlar ${ }^{33}$ Kararmışken uṣātuñ cümle-i ețāă u ebdānı

102. Ya şol mīzān u rehdür kim ' adālet anda ḳalmışdur Anuñçün ġayrınuñ șābit degüldür ' adl u iḥsānı

103. Ta' accüb eyleme inkārını rūy-1 tecāhülden Yirindeyken ḥasūd-1 münkirüñ iž ān u im` ānı

104. Remedden dìde gāhi ${ }^{\overline{34}}$ nūr-1 şemsi nefy ider țurmaz Seḳamdan tạ ${ }^{\complement} m-1$ ābı selb ider ālāt-1 iž ānı

105. Eyă $\bar{a}^{35}$ şol kimsenüñ ḩayrı kim anuñ sāḥa-i c izzin Dilerler țālib-i ‘ örf olanuñ riclān u rükbānı

106. Veyā żī-i' tibāra āyet-i kübrā-yı bī-şübhe Veyā żi-iğtināma ni`met-i ‘ uẓmā-yı Sübhānī

107. 'Aceb isrā olunduñ bir haremden ol birisine Şu bedr-āsā kim eyler leyle-i zulmāda seyrānı

108. Maḳām-1 ḳurb-1 Bārīden şuraya nā 'il olduñ kim ${ }^{36}$ Orada kimse ${ }^{37}$ kādir olmadı urmag̉a cevlānı

109. O rütbeyle seni kendülere takdim itdiler ${ }^{38}$ Şu taḳdīm ile kim eyler hadem mahdūmına anı

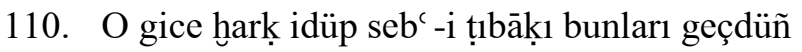
Şu cem` iyyetde kim olmışduñ ol cem` iyyetüñ hānı

\footnotetext{
${ }^{32}$ pür-şebemle: pür-şiyemle M1.

${ }^{33}$ bag̉lar: bag̉ışlar İ.

${ }^{34}$ dìide gāhī: gāhi dīide M2, İ.

${ }^{35}$ Eyā: Veyā S2.

${ }^{36}$ şuraya nā 'il olduñ kim: irişdüñ bir mahalle kim S2.

${ }^{37}$ Orada kimse: kimesne anda S2.

${ }^{38}$ takdim itdiler: itdiler takdìm İ.
} 
111. Kaçan żi-istibāḳa ḳomaduñsa hīçbir gāyet ${ }^{39}$ Ve bir żī-istināma pāye-i ‘ ulyā-yı sulțānı

112. Çıḳup hafż eyledüñ her yiri yirüñe iżāfetle Şu dem kim țutduñ aña ref ${ }^{r}$ ile bir rāh-1 ferdānı

113. Şu žāta vașl içün kim muhtefïdür ḩalḳ çeşminden Şu ma`ní ile kim Hakḳuñ odur bir sırr-ı pinhānı

114. Tedārük eyledüñ her mefharı bī-şirket-i gavrı Tecāvüz eyledüñ her menzil-i bì-zaḥmet-i cānı

115. Şu rütbet kim irişdüñ aña gāayet ḳadr-i `ālidür Şu ni` met kim virüldük kimse idrāk eylemez anı

116. Beşāret ehl-i İslāma ki yapıldı ‘ ināyetden Bir özge hāne kim aṣlā yıḳılmaz anuñ erkānı

117. Rüsülde ekrem itdiyse cenāb-1 ' izzetin Allāh Ümemde ekrem itdi ümmetini luṭf u iḥsānı

118. 'Idānuñ ḳalbine enbā' -1 ba' șet ḳorḳular șald1 Şu șavt-1 żi-hafā gibi ki tefrị̀ itdi mişānı

119. Me ārikde '1dāya şöyle urdı rumḥı ol şeh kim O rumḥ ile hikāyet eylediler laḥm-ı dükkānı

120. Firāra şöyle țālib oldılar kim ġıta itdiler ${ }^{40}$ Şu lạ̣muñ pāresine kim țutardı pāy-i ' $1 k ̣ b a ̄ n ı$

121. Geçerdi rūz u şeb tā gelmeyince ' add olunmaz idi Leyāl-i eşhür-i ḥurmuñ ser-i evḳāt u ezmānı

122. Bu dīn-i Ḥak şu ${ }^{41}$ ḳonuḳdur ki ḳonmış cāy-1 küffāra Şu ḳarm ile ki bulsa yirdi laḥm-ı ehl-i buṭlānı

\footnotetext{
${ }^{39}$ hiç bir gāayet: hịç gaāyet S2.

${ }^{40}$ itdiler: eylerdi İ.

${ }^{41}$ şu: şol S2.
} 
123. Çeküp baḥr-1 hamiss-i bìi-ḥisābın ol sebūh üzre Hemān olmışdı merdān-ı cihān emvāc-1 ‘ ummānı

124. Şu her żi-iḥtisāb-1 pür-icābetden ki ḳal' eyler Ser-i şemşiri-i bürrān ile aṣl-1 ${ }^{42}$ küfr ü țuggyānı

125. Şuraya nā'il oldı bunlaruñ imdād-ı dīni kim Belā-yı gurbetinden ṣoñra buldı vaṣl-1 cānānı

126. Kefālet eyledi hyayr-1 āb u ba' 1 ile ol Bāri Anuñ-çün görmedi milletde rūy-1 yütm ü hizlānı

127. Cebel gibi idi her biri hașmından su āl eyle Kim aña n'eylemişdür ța ne-i şemşīr-i bürrānı

128. Su āl eyle meḡāzìden saña bir bir beyān itsün Şu envā̄ -1 helāki kim vehamda görmedüñ anı

129. O şemşīr-i beyāżı ḳırmuzı ḳana boyarlardı Ser-i a' dāyı itdükçe çıḳup gerdān-1 meydānı

130. Yazarlardı haț-1 Yāḳūtı aḳlām-1 rimāḥ ile Komazdı harf-i cismi bunlaruñ bī-noḳta mürrānı

131. Silāḥı kāmil idi bunlaruñ sīmā ise her dem Selemden farḳ iderdi gūyiyā gül-berg-i ḩandānı

132. Saña nușret yeli ihdā iderdi neşr-i hoş-būyın Dürū‘ ında gül-i gonçe șanurduñ sen o merdānı

133. Zuhūr-1 haylde nebt-i rübā gibi idi bunlar Veli bā' is degüldi farṭ̂-1 şedd-i habl-i fürsānı

134. ' 'Idānuñ farț-1 şeddinden ḳulūbı şöyle ḳopdı kim 'Uyūnı farḳdan ḳaldı ser-i insān u ḥayvānı

42 aṣl-1: ehl-i M1. 
135. Resūl-i Ḥaḳ ile manșūr olanı dār-1 dünyāda Olurdı bişesinde görse idi şīr-i tersānn ${ }^{43}$

136. Veli senden görünmez şol ki manșūr olmamış ola 'Adūsından bulunmaz şol ki görmez rūy-1 hüsrānı

137. Çeküp etbā' 1 nı ḥırz-1 emān-1 dīne ḳondurdı Şu şìr-āsā kim eşbāline tụtdı bir neyistānı ${ }^{44}$

138. Kelāmu'llāh niçe ehl-i cidāli yirlere urdı Yahod niçe lecūcuñ burnın ${ }^{45}$ urdı dest-i burhānı

139. Zamān-1 cāhiliyyetde olan 'ilmi ile mu' ciz Yiter saña dem-i yütmindeki te'dīb-i Rabbānī

140. Bu medh ile o şehden istikāale eylerin her dem Şu ‘ ömri kim geçürdi naẓm u neșr-i dünye-i fāni

141. Kim anlar boynuma țaḳdı şunı kim ḳorḳulur șoñı Şu hedy-āsā kim āhir yirlere münșab olur ḳanı

142. Bu iki hāalde uydum șabā-yı bì ser ü pāya İhāṭa eyledi ețāfumı zenb ü peşimānı

143. Husāret şol dil-i dīvāneye kim vakt-i bey inde Virüp dünyā-yı dūnı almadı makṣūd-ı cānānı

144. Şu kim bey eyleye dīnini dünyāya olur ẓāhir Aña bir gabn-1 fāhiş kim getürmez fesh ${ }^{46}$ ü buṭlānı

145. Göñül 'iṣyān iderse ḥamdü-li’llāh kim ṣımaz 'ahdin O şehden pāre pāre olsa kesmez ḥabl-i ìmānı

146. Ki ben aña semiyy olmag ile bir zimmetin aldum $\mathrm{O}$ ise cümleden ${ }^{47} \mathrm{a}^{\mathrm{c}}$ lā ider ibḳā-y1 ${ }^{48}$ peymānı

\footnotetext{
${ }^{43}$ tersān1: hersānı S2; İ.

${ }^{44}$ bir neyistānı: cāy-1 sükkānı İ.

${ }^{45}$ burnın: boynın $\mathrm{S} 2$.

${ }^{46}$ fesh: feth S2.
} 
147. $M e^{c}$ ādümde eger țutmazsa destüm maḥż-1 luṭfından Ṭayanmaz mi ${ }^{49}$ ṣırāt üstinde cānuñ pāy-1 'ișyānı

148. Münezzehdür o kim mahrūm ide rācī-i elțāfin Yahod bìihtirām andan döne hualfina ${ }^{50}$ cỉrānı

149. Senāsın fikrüme ilzām idelden ol şehi buldum Şunuñ ḩayrı kim eyler iltizām-1 luṭf u iḥsānı

150. Yed-i muḥtācını anuñ ġnāsı fevt ü terk itmez Ḥayā inbāt ider rūy-1 ekemde verd-i handānı

151. Bu medh ile şunı ḳaṣd itmedüm ben ki o zehrāyı Züheyrüñ elleriyle düşürürdi medḥ-i sulțānı

152. Benüm ey ekrem-i 'âlem melāz u melce 'üm sensin Ḥulūl itdükde dehr-i pür-cefānuñ hutạb u hiidsānı

153. Benümle manșıb u cāhuñ habībā hiç teng olmaz Şu dem kim ol kerīm ahž eylese ${ }^{51}$ bu ‘ abd-i giryānı

154. Şehā bir ḳațredür dünyā vü ' uḳbā bahrr-1 cūduñdan 'Ulūmuñdan huaț-1 levḥ ü ḳalem bir reşḥ-i bārāni

155. Dilā kesme ümīdüñ zelle-i ' uẓmā ile Ḥaḳdan Kim anı bir șagìire gibi örter baḥr-1 gufrāni

156. Hudānuñ raḥmetin şöyle umarın vaḳt-i ḳısmetde Kim ol atı ola efkendesinüñ ḳadr-i ‘ iṣyānı

157. Cenābuñdan ${ }^{52}$ ümìd-i cānumı ' aks itme yā Rabb Müyesser eyle baña bir hịisāb-1 sehl ü āsānı

${ }^{47}$ cümleden: cümle M2.

${ }^{48}$ ibḳā-yı: ỉfā-yı S2.

${ }^{49} \mathrm{mi}$ : hiç S2.

${ }^{50}$ halfına: halkına S2.

${ }^{51}$ eylese: eyleye M2, İ.

${ }^{52}$ Cenābuñdan: Cenābuñda S1, S2, M3. 
158. Bu 'abd-i pür-ḳuṣūra luṭf u ị̣sān eyle her yirde

Ki cām-1 șabrını kesr itmesün seng-i perişānı

159. Seḥāb-1 luṭfuñı her demde irsāl eyle yağdursun

Resūl-i müstedāmuñ üstine bārān-1 ị̣sāni

160. Daḩ1 şol āl ü șaḥb u tābi i ine kim o serverler

Șıfăt-1 bì-bedelle aldılar miżmār u meydānı

161. Șabā gülşende taḥrik eyledükçe ' aźbe-i bānın

Ya 1ṭāb eyledükçe ' 'isi ḥādīi-i ${ }^{53}$ hoş-elhānı

\section{Sonuç}

Hz. Peygamber'e duyulan derin muhabbetin tezahürü olarak kaside nazım şekliyle kaleme alınan Kasîde-i Bürde, terim olarak Ka'b b. Züheyr ve Muhammed b. Saîd el-Bûsîrî adında Arap kökenli iki şairin yazdığı şiirler için kullanılagelmiştir. İslam coğrafyalarında olduğu gibi klasik Türk edebiyatında da çok rağbet gören bu iki kasideden İmam Bûsîr̂̂’nin kasidesi divan şairleri tarafindan daha fazla ilgiye mazhar olmuştur. Bu kaside, 15. yüzyıldan itibaren birçok şair veya mütercim tarafından defalarca şerh, tahmîs, tesdîs, tesbî‘, taştîr ve tercüme edilmiştir. Bunlar içinde onlarca şair tarafindan nazmen Türkçeye yapılan tercümeler hem sayıca fazla oluşları hem de edebî hüviyete sahip olmaları bakımından ayrı bir önemi haizdirler. Belli bir şöhreti yakalamış olan şairler dışında hayatı hakkında kaynaklarda oldukça sınırlı bilgi bulunan veya bu türde yazmış oldukları eserler sayesinde haberdar olduğumuz şairler de bulunmaktadır. Bunlardan biri de Paşa Sarayı Hocası sanıyla tanınan Fazlî’dir.

İmam Bûsîrî’nin kasidesini nazmen Türkçeye tercüme eden Fazlî’nin hayatı hakkında eldeki bilgiler yok denecek kadar azdır. Ancak eserin Millî Kütüphanede "06 Mil Yz A 3963/2" arşiv numaralı nüshasında müstensihi bu eserin Paşa Sarayı Hocası Fazlî Efendi tarafından 1036/162627 tarihinde nazmen tercüme edildiğini ve kendisinin de asıl nüshadan istinsahta bulunduğunu ifade etmiştir. Bu ifade hem eserin bu tarihte kaleme alındığını hem de mütercimin bu tarihte hayatta olduğunu göstermektedir.

Fazlî’nin 161 beyitten müteşekkil olan manzum tercümesi, Arapça 161 beyit olan kaynak metinle aynı beyit sayısına sahip olsa da yazılmış olduğu vezin kalıbı ve kafiye itibarıla kaynak metinden farklılık arz etmektedir. Şairin hem aruz hem de kafiye tatbikinde belirgin hatalara düştüğünü söylemek mümkün değildir.

Muhteva bakımından Bûsîr̂’’nin kasidesinde olduğu gibi 10 bölüme sahip olan eserde Fazlî, kaynak metindeki dile getirilenleri bir şair olarak tekrar nazım kalıbında şekillendirerek Türkçeye tercüme etmede oldukça başarılı olmuştur. Kaynak metnin muhtevasına uygun fakat birebir tercüme

\footnotetext{
${ }^{53}$ ḥādīi-i: ḥādīnüñ M2.
} 
yolunu tercih etmeyen şair, bazı kelime ve ibarelere Türkçe karşılık bulmada birçok mütercim gibi zorlanmış olsa da bu zorlukları kaynak eserdeki bazı kelimeleri aynen tekrar ederek veya bu kelimelere karşılık Arapça veya Farsça kökenli kelimeleri kullanarak aşmaya çalışmıştır.

Fazlî’nin akıcı bir üslupla İmam Bûsîr̂̂’nin kasidesinde dile getirdiği düşüncelerin kendi ruhunda oluşturduğu vecd hâlini samimi bir edayla ifadeye çalıştı̆g bu manzum Kasîde-i Bürde Tercümesi, aynı türde kaleme alınan bazı eserlerle ortak özelliklere sahiptir. Bu meyanda eser, vezin itibarıyla Zâtî ve Kemâlâtî Mehmed'in; kafiye bakımından da Zâtî ve Şemseddin Sivâsî'nin manzum tercümeleriyle ortak özelliklere sahiptir.

\section{Kaynakça}

AKSOYAK, İsmail Hakkı (2013). "Fazlî, Vardarlı Fazlî”. Türk Edebiyatı Isimler Sözlüğ̈̈, http://teis.yesevi.edu.tr/madde-detay/fazli-vardarli-fazli, [Erişim Tarihi: 15.03.2021].

ALBAYRAK SAK, Vesile (2014). "Şemseddin Sivâsî’nin Kasîde-i Bürde Tercümesi”. Turkish Studies, 9/3, 91-110.

ALBAYRAK SAK, Vesile (2019). "Esâsî'nin Kasîde-i Bürde Tercümesi". Rumelide Dil ve Edebiyat Araştırmaları Dergisi, 16, 343-363.

ALICI, Lütfi (2004). “Arif Süleyman ve Hilye-i Nebî Adlı Eseri”. Akademik Araştırmalar Dergisi, 22, 129-48.

AYÇiçEĞİ, Bünyamin (2015). "Bûsîrî’nin Kasîdetü'l-Bürde’sinin Diyarbakırlı Mehmed Said Paşa Tarafindan Yapılan Mensur ve Manzum Tercümesi”, Divan Edebiyatı Araştırmaları Dergisi, 15, 27-102.

ÇELEBİOĞLU, Âmil (1988). "Türk Edebiyatında Manzum Dinî Eserler”, Eski Türk Edebiyatı Araştırmaları, İstanbul: MEB Yayınları.

DEMIRAYAK, Kenan (2001). "Kasîdetü'l-Bürde”, Türkiye Diyanet Vakfi İslam Ansiklopedisi. İstanbul: TDV Yayınları, 24, 566-567.

KAHRAMAN, Bahattin (1997). "Le‘âlî ve Abdurrahim Karahisarî’nin Manzum Kasîde-i Bürde Tercümeleri”, Türkiyat Araştırmaları Dergisi, 4, 57-107.

Kasîdetü'l-Bürde ve Tercümesi. Millî Kütüphane Yazmalar Koleksiyonu, 06 Mil Yz FB 149.

KAYA, Mahmut (2001). "Kasîdetü'l-Bürde". Türkiye Diyanet Vakfi İslam Ansiklopedisi. İstanbul: TDV Yayınları, 24, 568-569.

KOÇ, Hamza (2018). “Ahmed-i Rıdvan'ın Manzum Kaside-i Bürde Tercümesi”. Osmanlı Mirası Araştırmaları Dergisi, 5/12, 9-31.

SEZER, İsmail Hakk1 (1985). İmam Bûsîrî ve Bürde'si. Konya: Selçuk Üniversitesi, SBE Doktora Tezi.

ŞAHIN, Ebubekir Sıddık (1997). Kaside-i Bürde'nin Türkçe Şerh ve Tercümeleri. Ankara: Gazi Üniversitesi, SBE Yüksek Lisans Tezi. 
Şerh-i Kasîdetü'l-Bürde. Millî Kütüphane Yazmalar Koleksiyonu, 06 Mil Yz A 4639/1.

Terceme-i Kasîdetü'l-Bürde. Millî Kütüphane Yazmalar Koleksiyonu, 06 Mil Yz A 3963/2.

Terceme-i Kasîdetü'l-Bürde. Millî Kütüphane Yazmalar Koleksiyonu, 60 Zile 444/1.

Terceme-i Kasîdetü’l-Bürde. Ankara Üniversitesi İlahiyat Fakültesi Kütüphanesi, EY 0747.

Terceme-i Kasîdetü'l-Bürde. Süleymaniye Kütüphanesi, İbrahim Efendi $878 / 3$.

Terceme-i Kasîdetü'l-Bürde. Süleymaniye Kütüphanesi, Reşid Efendi 826.

YAZAR, Sadık (2011). Anadolu Sahası Klâsik Türk Edebiyatında Tercüme ve Şerh Geleneği. İstanbul: İstanbul Üniversitesi, SBE Doktora Tezi.

YAZAR, Sadık (2018). "Amasyalı Seyyid Hüseyin Efendi ve Manzum Kasîde-i Bürde Tercümesi”, Amasya Üniversitesi Sosyal Bilimler Dergisi, 2/3, 145-187.

YILMAZ, Ali (2012). Türk İslam Edebiyatı El Kitabı. Ankara: Grafiker Yayınları.

YÜCEL, Yusuf İbrahim (2016). "Kaside-i Bürde Üzerine Son Dönemde Yapılan İlmi Çalışmalar”, İslam Bilimleri Araştırmaları Dergisi, 1, 86-106. 


\section{Ekler}

Fazlî’nin Manzum Kasîde-i Bürde Tercümesi'nin Süleymaniye Kütüphanesi "Reşid Efendi 826" Numaralı Nüshasının İlk ve Son Varakları
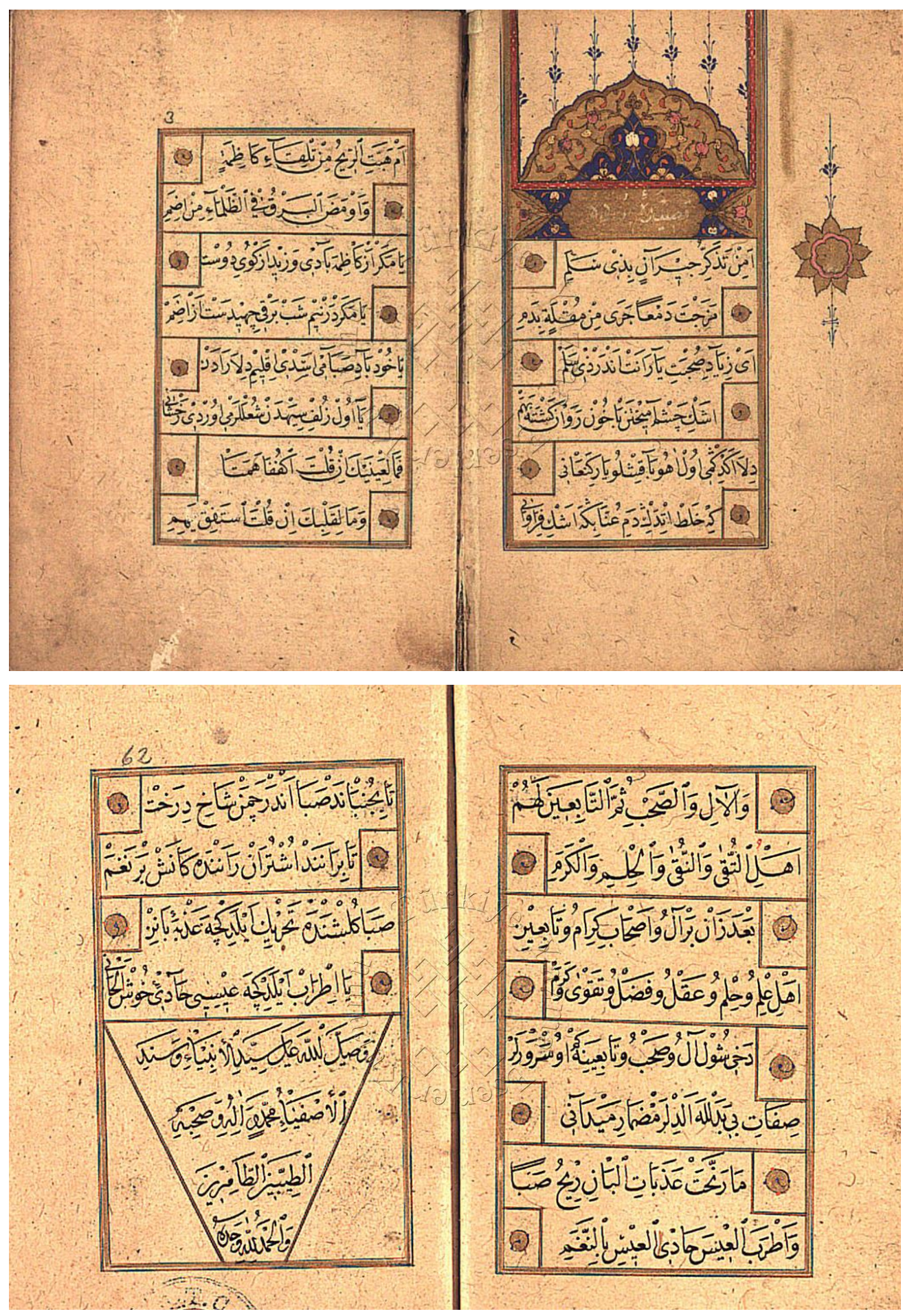